\title{
Saccharopolyspora halophila sp. nov., a novel halophilic actinomycete isolated from a saline lake in China
}

\author{
Shu-Kun Tang, ${ }^{1}$ Yun Wang, ${ }^{2}$ Man Cai, ${ }^{1}$ Xiao-Yang Zhi, ${ }^{1}$ Kai Lou, ${ }^{2}$ \\ Li-Hua Xu, ${ }^{1}$ Cheng-Lin Jiang ${ }^{1}$ and Wen-Jun Li ${ }^{1}$ \\ ${ }^{1}$ The Key Laboratory for Microbial Resources of the Ministry of Education and Laboratory for \\ Conservation and Utilization of Bio-Resources, Yunnan Institute of Microbiology, Yunnan \\ University, Kunming, Yunnan 650091, PR China \\ ${ }^{2}$ Xinjiang Institute of Microbiology, Xinjiang Academy of Agricultural Science, Urumqi, Xinjiang \\ 830091, PR China
}

Correspondence

Wen-Jun Li

wjli@ynu.edu.cn

or

liact@hotmail.com

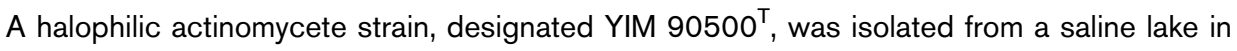
Xinjiang province, north-west China and subjected to a polyphasic taxonomic study. Good growth of the novel isolate occurred at $28-37{ }^{\circ} \mathrm{C}, \mathrm{pH} 7-8$ and with $10-15 \%(w / v) ~ N a C l$; no growth occurred without any salts. Strain YIM $90500^{\top}$ contained meso-diaminopimelic acid with glucose, arabinose and ribose as the whole-cell sugars. The major phospholipids were phosphatidylcholine and diphosphatidylglycerol. MK-9 $\left(\mathrm{H}_{4}\right)$ was the predominant menaquinone. The major fatty acids were iso- $C_{15: 0}$, iso- $C_{16: 0}$ and anteiso- $C_{17: 0}$. The chemotaxonomic data together with the

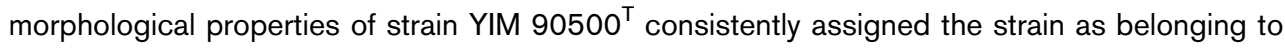
the genus Saccharopolyspora. Phylogenetic analysis based on 16S rRNA gene sequences further revealed that strain YIM $90500^{\top}$ formed a distinct phyletic lineage in the genus Saccharopolyspora and showed low 16S rRNA gene similarities (<96.4\%) with other species of the genus. On the basis of the evidence from the polyphasic study, a novel species, Saccharopolyspora halophila sp. nov., is proposed. The type strain is YIM $90500^{\top}$ (=DSM $45007^{\top}=$ KCTC $19162^{\top}$ ).
\end{abstract}

The genus Saccharopolyspora was first described by Lacey \& Goodfellow (1975) and it currently comprises 13 species with validly published names: S. hirsuta (Lacey \& Goodfellow, 1975), S. erythraea (Labeda, 1987), S. taberi (Labeda, 1987; Korn-Wendisch et al., 1989), S. gregorii (Goodfellow et al., 1989), S. hordei (Goodfellow et al., 1989), S. rectivirgula (Korn-Wendisch et al., 1989), S. spinosa (Mertz \& Yao, 1990), S. spinosporotrichia (Zhou et al., 1998), S. flava (Lu et al., 2001), S. thermophila (Lu et al., 2001), S. antimicrobica (Yuan et al., 2008), S. cebuensis (PimentelElardo et al., 2008) and S. shandongensis (Zhang et al., 2008). All the above-mentioned species of the genus Saccharopolyspora are non-halophilic actinomycetes.

Strain YIM $90500^{\mathrm{T}}$ was isolated from a hypersaline sample collected from a saline lake in Xinjiang, after 3 weeks incubation at $37{ }^{\circ} \mathrm{C}$ on cellulose-casein multi-salt (CCMS) medium. The composition of the CCMS medium was $\left(1^{-1}\right.$ distilled water): $10 \mathrm{~g}$ microcrystalline cellulose (MCC),

The GenBank/EMBL/DDBJ accession number for the 16S rRNA gene sequence of strain YIM $90500^{\top}$ is DO923129.

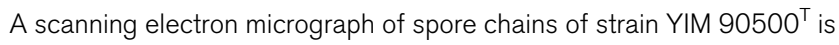
available as supplementary material with the online version of this paper.
$0.3 \mathrm{~g}$ casein, $0.2 \mathrm{~g} \mathrm{KNO}_{3}, 0.5 \mathrm{~g} \mathrm{~K}_{2} \mathrm{HPO}_{4}, 0.02 \mathrm{~g} \mathrm{CaCO}_{3}$, $0.01 \mathrm{~g} \mathrm{FeSO}_{4}, 150 \mathrm{~g} \mathrm{NaCl}, 30 \mathrm{~g} \mathrm{MgCl}_{2} .6 \mathrm{H}_{2} \mathrm{O}, 20 \mathrm{~g} \mathrm{KCl}$ and $15 \mathrm{~g}$ agar. Multi-salts, including $\mathrm{NaCl}, \mathrm{KCl}$ and $\mathrm{MgCl}_{2} \cdot 6 \mathrm{H}_{2} \mathrm{O}$, was sterilized separately before being added to the medium. The $\mathrm{pH}$ of the medium was adjusted to $\mathrm{pH} 7.5$ with $1 \mathrm{M} \mathrm{NaOH}$. The strain was maintained on ISP medium 4 (Shirling \& Gottlieb, 1966) agar slants containing $10 \%(\mathrm{w} / \mathrm{v}) \mathrm{NaCl}$ at $4{ }^{\circ} \mathrm{C}$ and as suspensions of mycelium fragments in glycerol $(20 \%, \mathrm{v} / \mathrm{v})$. Biomass for chemical and molecular studies was obtained by cultivation in shaken flasks (about 150 r.p.m.) using ISP medium 4 [10\% (w/v) $\mathrm{NaCl}, \mathrm{pH} 7.5]$ at $37{ }^{\circ} \mathrm{C}$ for 2 weeks.

Morphological characteristics of strain YIM $90500^{\mathrm{T}}$ were observed by light microscopy (model BH 2; Olympus) and scanning electron microscopy (JSM5600LV; JEOL) after 21 days growth on ISP 4 agar medium containing $10 \%$ $(\mathrm{w} / \mathrm{v}) \mathrm{NaCl}$. Cultural characteristics were determined after 3-4 weeks according to the methods used in the International Streptomyces Project (ISP) (Shirling \& Gottlieb, 1966). All media were supplemented with $10 \%$ $(\mathrm{w} / \mathrm{v}) \mathrm{NaCl}$ for growth. The colours of substrate and aerial mycelia and any soluble pigments produced were determined by comparison with chips from the ISCC-NBS 
colour charts (Kelly, 1964). Media and procedures used to determine physiological features and carbon source utilization were those described by Williams et al. (1989). Acid production from carbohydrates was assessed using media and methods described by Williams et al. $(1983)$. The growth temperature was tested at $4,10,20$, $28,37,45,55$ and $65{ }^{\circ} \mathrm{C}$ on ISP medium 4 containing $10 \%(\mathrm{w} / \mathrm{v}) \mathrm{NaCl}$. For $\mathrm{NaCl}$ tolerance experiments, ISP medium 4 was used as the basal medium. The following $\mathrm{NaCl}$ concentrations (w/v) were used: $0,1,3,5,10,15$, 20,25 and $30 \%$. The $\mathrm{pH}$ range for growth was investigated between 4.0-10.0 at intervals of $1 \mathrm{pH}$ unit, using the buffer system: $\mathrm{pH}$ 4.0-5.0: $0.1 \mathrm{M}$ citric acid/ $0.1 \mathrm{M}$ sodium citrate; $\mathrm{pH}$ 6.0-8.0: $0.1 \mathrm{M} \mathrm{KH}_{2} \mathrm{PO}_{4} / 0.1 \mathrm{M}$ $\mathrm{NaOH}$; pH 9.0-10.0: 0.1 M NaHCO $3 / 0.1 \mathrm{M} \mathrm{Na}_{2} \mathrm{CO}_{3}$.

Strain YIM $90500^{\mathrm{T}}$ developed well on most media; the detailed results are given in the species description. Substrate mycelia were long and well developed. Aerial mycelia were well developed and long spore chains were borne on the aerial mycelium. All spores were non-motile, smooth-surfaced, oval or spherical and 0.6-0.7 $\times 0.6-$ $1.1 \mu \mathrm{m}$ in size (Supplementary Fig. S1, available in IJSEM Online). Good growth occurred at $28-37{ }^{\circ} \mathrm{C}$ and at $\mathrm{pH} 7-8$ with $10-15 \%(\mathrm{w} / \mathrm{v}) \mathrm{NaCl}$. The detailed physiological and biochemical characteristics of the strain are given in Table 1 and in the species description.

Isomers of diaminopimelic acid and whole-cell sugars were analysed according to the procedures developed by Hasegawa et al. (1983). Polar lipids were extracted and examined by using two-dimensional TLC and identified using previously described procedures (Minnikin et al., 1984). Menaquinones were isolated according to Minnikin et al. (1984) and separated by HPLC (Kroppenstedt, 1982). Cellular fatty acids analysis was performed as described by Sasser (1990) using the Microbial Identification System (MIDI). Strain YIM $90500^{\mathrm{T}}$ contained meso-diaminopimelic acid as the cell wall diamino acid, with glucose, arabinose and ribose as the major whole-cell sugars. The major cellular fatty acids were iso- $\mathrm{C}_{15: 0}(20.8 \%)$, iso- $\mathrm{C}_{16: 0}$ $(19.1 \%)$ and anteiso- $\mathrm{C}_{17: 0}(21.0 \%)$; minor fatty acids iso$\mathrm{C}_{14: 0}(1.2 \%)$, anteiso- $\mathrm{C}_{15: 0}(6.2 \%), \mathrm{C}_{16: 1} \omega 7 \mathrm{c} /$ iso- $\mathrm{C}_{15: 0} 2-$ $\mathrm{OH}(3.4 \%), \mathrm{C}_{16: 0}(3.5 \%), 10$-methyl $\mathrm{C}_{16: 0}(6.3 \%)$, iso$\mathrm{C}_{17: 0}(7.0 \%), \mathrm{C}_{17: 1} \omega 8 c(2.3 \%), \mathrm{C}_{17: 0}(1.2 \%), 10$-methyl $\mathrm{C}_{17: 0}(1.8 \%)$ and $\mathrm{C}_{18: 1} \omega 9 c(1.3 \%)$ were also detected. Detailed data for phospholipids and menaquinones are given in the species description.

Extraction of genomic DNA and PCR amplification of the 16S rRNA gene were done as described by Li et al. (2007). Multiple alignments with sequences of the most closely related Saccharopolyspora species and calculations of levels of sequence similarity were carried out using CLUSTAL_X (Thompson et al., 1997). Phylogenetic analyses were performed using three tree-making algorithms, neighbour-joining (Saitou \& Nei, 1987), maximum-likelihood (Felsenstein, 1981) and maximum-parsimony (Fitch, 1971). A phylogenetic tree was constructed using the neighbour-joining method of Saitou \& Nei (1987) from $K_{\text {nuc }}$ values (Kimura, 1980) using MEGA version 2.1 (Kumar et al., 2001). The topology of the phylogenetic tree was evaluated by using the bootstrap resampling method of

Table 1. Differential phenotypic and chemotaxonomic characteristics between strain $\mathrm{YIM} 90500^{\top}$ and its closest neighbours of the genus Saccharopolyspora

Strains: 1, YIM $90500^{\mathrm{T}}$ (S. halophila sp. nov.); 2, S. flava AS4.1520 ${ }^{\mathrm{T}} ; 3$, S. thermophila AS4.1511 ${ }^{\mathrm{T}} ; 4$, S. spinosa DSM $44228^{\mathrm{T}}$. Data for organisms other than strain YIM $90500^{\mathrm{T}}$ are from Mertz \& Yao (1990) and Lu et al. (2001). +, Positive; -, negative; ND, not determined.

\begin{tabular}{|c|c|c|c|c|}
\hline Characteristic & 1 & 2 & 3 & 4 \\
\hline Fragments of substrate mycelium & - & + & + & + \\
\hline \multicolumn{5}{|l|}{ Colour of ${ }^{*}:$} \\
\hline Aerial mycelia & WY & W & W & YP \\
\hline Substrate mycelia & $\mathrm{Y}-\mathrm{OY}$ & $\mathrm{Y}$ & $\mathrm{C}-\mathrm{Bf}$ & $\mathrm{Y}-\mathrm{YBr}$ \\
\hline Soluble pigment & - & - & - & + \\
\hline \multicolumn{5}{|l|}{ Degradation of: } \\
\hline Adenine & - & + & + & - \\
\hline Casein & + & - & - & + \\
\hline Starch & - & + & + & - \\
\hline Tyrosine & + & - & + & + \\
\hline Reduction of nitrate & + & + & - & + \\
\hline $\mathrm{NaCl}$ range for growth $(\%, w / v)$ & $3-20$ & $0-7$ & $0-7$ & $0-11$ \\
\hline Temperature range for growth $\left({ }^{\circ} \mathrm{C}\right)$ & $10-45$ & $28-37$ & $45-55$ & $15-37$ \\
\hline Menaquinones & MK-9 $\left(\mathrm{H}_{2}\right)$, MK-9 $\left(\mathrm{H}_{4}\right)$, MK-9 $\left(\mathrm{H}_{6}\right)$ & MK-9 $\left(\mathrm{H}_{4}\right)$ & MK-9 $\left(\mathrm{H}_{6}\right), \mathrm{MK}-9\left(\mathrm{H}_{8}\right)$ & MK-9 $\left(\mathrm{H}_{4}\right)$, MK-9 $\left(\mathrm{H}_{6}\right)$ \\
\hline Polar lipids $\dagger$ & DPG, PC, PI & PC & $\mathrm{ND}$ & DPG, PC \\
\hline DNA G $+C$ content $(\mathrm{mol} \%)$ & 66.3 & 67 & 73.1 & ND \\
\hline
\end{tabular}

${ }^{*} \mathrm{Bf}$, buff; Br, brown; C, colourless; O, orange; P, pink; W, white; Y, yellow.

$\dagger$ DPG, Diphosphatidylglycerol; PC, phosphatidylcholine; PI, phosphatidylinositol. 
Felsenstein (1985) with 1000 replicates. For the determination of the $\mathrm{G}+\mathrm{C}$ content, the genomic DNA of strain YIM $90500^{\mathrm{T}}$ was prepared according to the method of Marmur (1961). The G + C content of the DNA was determined by using reversed-phase HPLC of nucleosides, according to Mesbah et al. (1989).

The results of the 16S rRNA gene sequence comparison clearly demonstrated that strain YIM $90500^{\mathrm{T}}$ is a member of the genus Saccharopolyspora. In the phylogenetic tree based on the neighbour-joining algorithm, strain YIM $90500^{\mathrm{T}}$ formed a distinct subclade with $S$. flava, and both shared the same branch with a high bootstrap value of $97 \%$ (Fig. 1). Topologies of phylogenetic trees constructed using the maximum-likelihood and maximum-parsimony algorithms were similar to those of the tree constructed by using neighbour-joining analysis (data not shown). The $16 \mathrm{~S}$ rRNA gene sequence similarities between strain YIM $90500^{\mathrm{T}}$ and its closest neighbours, S. spinosa and S. flava, were 96.3 and $96.2 \%$, respectively. The $\mathrm{G}+\mathrm{C}$ content of the DNA was $66.3 \mathrm{~mol} \%$.

On the basis of the differential phenotypic and chemotaxonomic characteristics (Table 1) and the phylogenetic data of strain YIM $90500^{\mathrm{T}}$ and its closest neighbours in the genus Saccharopolyspora, strain YIM $90500^{\mathrm{T}}$ merits recognition as representing a novel species within the genus, for which we propose the name Saccharopolyspora halophila sp. nov.

\section{Description of Saccharopolyspora halophila sp. nov.}

Saccharopolyspora halophila (ha.lo.phi'la. Gr. n. hals halos, salt; Gr. adj. philos, loving; N.L. fem. adj. halophila, saltloving, referring to the ability to grow at high $\mathrm{NaCl}$ concentrations).

Aerobic, Gram-positive, moderately halophilic filamentous actinomycete. Substrate mycelia are well-developed and no fragments are observed. Aerial mycelia form long chains of spores; spores are non-motile, smooth-surfaced, oval or spherical and $0.6-0.7 \times 0.6-1.1 \mu \mathrm{m}$ in size. Good growth occurs on Czapek agar, yeast extract-malt extract, potato agar, glycerol/asparagine agar and inorganic salts-starch agar. Moderate growth occurs on nutrient agar and oatmeal agar. Aerial mycelia are white-yellow in colour and substrate mycelia are yellow to moderate orange-yellow. No diffusible pigments are produced. Casein and tyrosine are degraded, but adenine, cellulose and chitin are not. Tests for gelatin liquefaction, nitrate reduction and milk peptonization and coagulation are positive and tests for $\mathrm{H}_{2} \mathrm{~S}$ and melanin production and starch hydrolysis are negative. L-Arabinose, cellobiose, D-fructose, D-galactose, D-glucose, myo-inositol, D-lactose, maltose, D-mannitol, D-mannose, raffinose, Lrhamnose, sucrose, sodium acetate, D-xylitol and D-xylose are utilized as carbon sources, whereas D-sorbitol and trehalose are not. Acid production occurs on L-arabinose, D-glucose, myo-inositol, L-rhamnose and D-xylose. Growth occurs on alanine, asparagine, arginine, cystine, glycine, histidine, homocysteine, hypoxanthine, lysine, praline, threonine, tyrosine, valine and urea as nitrogen sources, but not on adenine, hydroxyproline or glutamate. Major phospholipids are phosphatidylcholine and diphosphatidylglycerol; minor amounts of phosphatidylinositol are also detected. Menaquinones are MK-9 $\left(\mathrm{H}_{2}\right)$, MK-9 $\left(\mathrm{H}_{4}\right)$ and MK$9\left(\mathrm{H}_{6}\right)$ (ratio of peak areas, 13.1:82.9:3.9). Major cellular fatty acids are iso- $\mathrm{C}_{15: 0}$, iso- $\mathrm{C}_{16: 0}$ and anteiso- $\mathrm{C}_{17: 0}$; minor fatty acids iso- $\mathrm{C}_{14: 0}$, anteiso- $\mathrm{C}_{15: 0}, \mathrm{C}_{16: 1} \omega 7 c /$ iso- $\mathrm{C}_{15: 0} 2$ $\mathrm{OH}, \mathrm{C}_{16: 0}, 10$-methyl $\mathrm{C}_{16: 0}$, iso- $\mathrm{C}_{17: 0}, \mathrm{C}_{17: 1} \omega 8 c, \mathrm{C}_{17: 0}, 10$ methyl $C_{17: 0}$ and $C_{18: 1} \omega 9 c$ are also detected. Temperature, $\mathrm{pH}$ and $\mathrm{NaCl}$ tolerance ranges are $10-45{ }^{\circ} \mathrm{C}, \mathrm{pH}$ 6-8.5 and $3-20 \%(\mathrm{w} / \mathrm{v})$, respectively. Good growth occurs at $28-37{ }^{\circ} \mathrm{C}$ and $\mathrm{pH} 7-8$ and with $10-15 \%(\mathrm{w} / \mathrm{v}) \mathrm{NaCl}$. The $\mathrm{G}+\mathrm{C}$ content of the DNA of the type strain is $66.3 \mathrm{~mol} \%$.

The type strain, YIM $90500^{\mathrm{T}}\left(=\mathrm{DSM} \quad 45007^{\mathrm{T}}=\mathrm{KCTC}\right.$ $\left.19162^{\mathrm{T}}\right)$, was isolated from a saline lake in Xinjiang, northwest China.

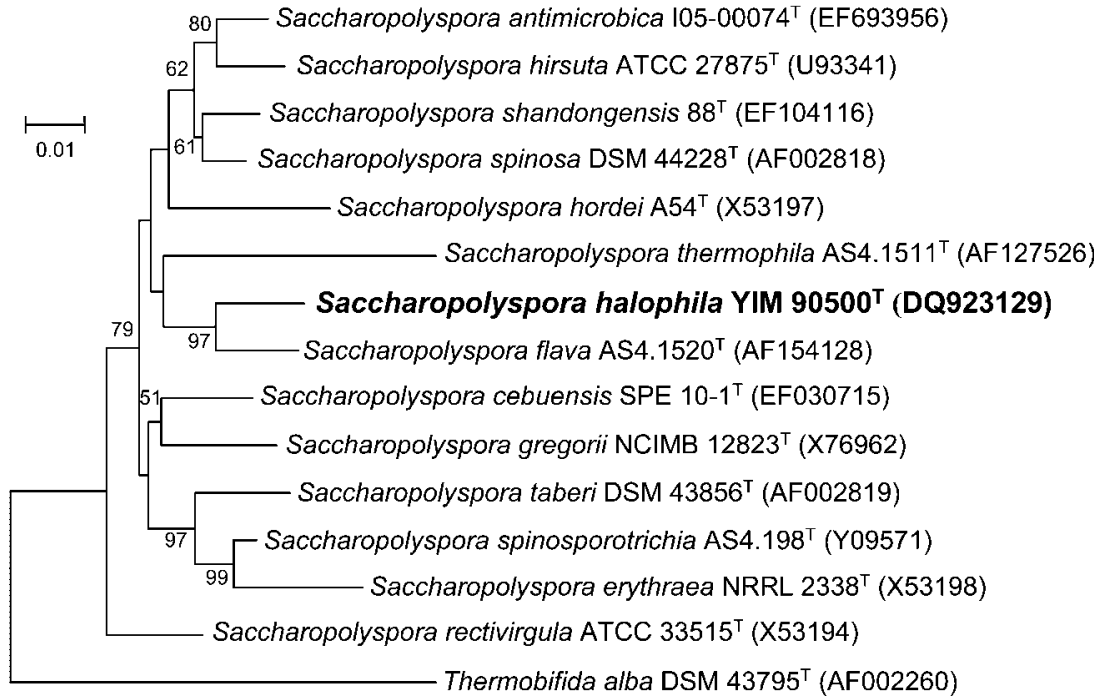

Fig. 1. Phylogenetic dendrogram obtained by using distance matrix analysis of 16S rRNA gene sequences, showing the position of strain YIM $90500^{\top}$ and related phylogenetic neighbours. Numbers at branch nodes are bootstrap values (1000 resamplings; only values over $50 \%$ are given). The sequence of Thermobifida alba DSM 43795 ${ }^{\top}$ (AF002260) was used as the outgroup. Bar, $1 \%$ sequence divergence. 


\section{Acknowledgements}

This research was supported by the National Basic Research Program of China (no. 2004CB719601), the National Natural Science Foundation of China (nos 30600001, 30860002, 30870005), the Ministry of Science of Technology, PR China (2006DFA33550), and the Open Project Program of the Extremophiles Lab of Xinjiang (no. XJYS0203-2005-01). W.-J. Li was supported by the Program for New Century Excellent Talents in University.

\section{References}

Felsenstein, J. (1981). Evolutionary trees from DNA sequences: a maximum likelihood approach. J Mol Evol 17, 368-376.

Felsenstein, J. (1985). Confidence limits on phylogenies: an approach using the bootstrap. Evolution 39, 783-791.

Fitch, W. M. (1971). Toward defining the course of evolution: minimum change for a specific tree topology. Syst Zool 20, 406-416.

Goodfellow, M., Lacey, J., Athalye, M., Embley, T. M. \& Bowen, T. (1989). Saccharopolyspora gregorii and Saccharopolyspora hordei: two new actinomycete species from fodder. J Gen Microbiol 135, 2125-2139.

Hasegawa, T., Takizawa, M. \& Tanida, S. (1983). A rapid analysis for chemical grouping aerobic actinomycetes. J Gen Appl Microbiol 29, 319-322.

Kelly, K. L. (1964). Inter-Society Color Council-National Bureau of Standards Color-Name Charts Illustrated with Centroid Colors. Washington, DC: US Government Printing Office.

Kimura, M. (1980). A simple method for estimating evolutionary rates of base substitutions through comparative studies of nucleotide sequences. J Mol Evol 16, 111-120.

Korn-Wendisch, F., Kempf, A., Grund, E., Kroppenstedt, R. M. \& Kutzner, H. J. (1989). Transfer of Faenia rectivirgula Kurup and Agre 1983 to the genus Saccharopolyspora Lacey and Goodfellow 1975, elevation of Saccharopolyspora hirsuta subsp. taberi Labeda 1987 to species level, and emended description of the genus Saccharopolyspora. Int J Syst Bacteriol 39, 430-441.

Kroppenstedt, R. M. (1982). Separation of bacterial menaquinones by HPLC using reverse phase (RP 18) and a silver loaded ion exchanger as stationary phases. J Liq Chromatogr 5, 2359-2387.

Kumar, S., Tamura, K., Jakobsen, I. B. \& Nei, M. (2001). MEGA2: molecular evolutionary genetics analysis software. Bioinformatics 17, 1244-1245.

Labeda, D. P. (1987). Transfer of the type strain of Streptomyces erythraeus (Waksman, 1923) Waksman and Henrici 1948 to the genus Saccharopolyspora Lacey and Goodfellow 1975 as Saccharopolyspora erythraea sp. nov., and designation of a neotype strain for Streptomyces erythraeus. Int J Syst Bacteriol 37, 19-22.

Lacey, J. \& Goodfellow, M. (1975). A novel actinomycete from sugarcane bagasse: Saccharopolyspora hirsuta gen. et sp. nov. J Gen Microbiol 88, 75-85.
Li, W. J., Xu, P., Schumann, P., Zhang, Y. Q., Pukall, R., Xu, L. H., Stackebrandt, E. \& Jiang, C. L. (2007). Georgenia ruanii sp. nov., a novel actinobacterium isolated from forest soil in Yunnan (China) and emended description of the genus Georgenia. Int J Syst Evol Microbiol 57, 1424-1428.

Lu, Z., Liu, Z., Wang, L., Zhang, Y., Qi, W. \& Goodfellow, M. (2001). Saccharopolyspora flava sp. nov. and Saccharopolyspora thermophila sp. nov., novel actinomycetes from soil. Int J Syst Evol Microbiol 51, 319-325.

Marmur, J. (1961). A procedure for the isolation of deoxyribonucleic acid from microorganisms. J Mol Biol 3, 208-218.

Mertz, F. P. \& Yao, R. C. (1990). Saccharopolyspora spinosa sp. nov., isolated from soil collected in a sugar mill rum still. Int J Syst Bacteriol 40, 34-39.

Mesbah, M., Premachandran, U. \& Whitman, W. B. (1989). Precise measurement of the $\mathrm{G}+\mathrm{C}$ content of deoxyribonucleic acid by highperformance liquid chromatography. Int J Syst Bacteriol 39, 159-167.

Minnikin, D. E., O’Donnell, A. G., Goodfellow, M., Alderson, G., Athalye, M., Schaal, A. \& Parlett, J. H. (1984). An integrated procedure for the extraction of bacterial isoprenoid quinones and polar lipids. J Microbiol Methods 2, 233-241.

Pimentel-Elardo, S. M., Tiro, L. P., Grozdanov, L. \& Hentsche, U. (2008). Saccharopolyspora cebuensis sp. nov., a novel actinomycete isolated from a Philippine sponge (Porifera). Int J Syst Evol Microbiol 58, 628-632.

Saitou, N. \& Nei, M. (1987). The neighbor-joining method: a new method for reconstructing phylogenetic trees. Mol Biol Evol 4, 406-425.

Sasser, M. (1990). Identification of bacteria by gas chromatography of cellular fatty acids. USFCC Newsl 20, 16.

Shirling, E. B. \& Gottlieb, D. (1966). Methods for characterization of Streptomyces species. Int J Syst Bacteriol 16, 313-340.

Thompson, J. D., Gibson, T. J., Plewniak, F., Jeanmougin, F. \& Higgins, D. G. (1997). The CLUSTAL_X windows interface: flexible strategies for multiple sequence alignment aided by quality analysis tools. Nucleic Acids Res 25, 4876-4882.

Williams, S. T., Goodfellow, M., Alderson, G., Wellington, E. M. H., Sneath, P. H. A. \& Sackin, M. J. (1983). Numerical classification of Streptomyces and related genera. J Gen Microbiol 129, 1743-1813.

Williams, S. T., Goodfellow, M. \& Alderson, G. (1989). Genus Streptomyces Waksman and Henrici 1943, 339 ${ }^{\mathrm{AL}}$. In Bergey's Manual of Systematic Bacteriology, vol. 4, pp. 2452-2492. Edited by S. T. Williams, M. E. Sharpe \& J. G. Holt. Baltimore: Williams \& Wilkins.

Yuan, L.-J., Zhang, Y.-Q., Guan, Y., Wei, Y.-Z., Li, Q. P., Yu, L.-Y., Li, W.-J. \& Zhang, Y.-Q. (2008). Saccharopolyspora antimicrobica sp. nov., an actinomycete from soil. Int J Syst Evol Microbiol 58, 1180-1185.

Zhang, J., Wu, D., Zhang, J., Liu, Z. \& Song, F. (2008). Saccharopolyspora shandongensis sp. nov., isolated from wheat-field soil. Int $J$ Syst Evol Microbiol 58, 1094-1099.

Zhou, Z. H., Liu, Z. H., Qian, Y. D., Kim, S. B. \& Goodfellow, M. (1998). Saccharopolyspora spinosporotrichia sp. nov., a novel actinomycete from soil. Int J Syst Bacteriol 48, 53-58. 